\title{
Middle to late Archaean geology of the eastern Baltic shield, with a note on its similarity and contrast with the Archaean of southern India
}

\author{
R SRINIVASAN ${ }^{1}, \mathrm{~K}^{\text {NAHA }}{ }^{2}, \mathrm{Y} \mathrm{J} \mathrm{BHASKAR} \mathrm{RAO}^{1}$, A B VREVSK $\mathrm{Y}^{3}$, \\ S I RYBAKOV 4 , A I GOLUBEV ${ }^{4}$ and M EFIMOV 5 \\ 'National Geophysical Research Institute, Uppal Road, Hyderabad 500007, India \\ ${ }^{2}$ Department of Geology and Geophysics, Indian Institute of Technology, Kharagpur \\ 721302 , India \\ ${ }^{3}$ Institute of Precambrian Geology, St. Petersberg, Russia \\ ${ }^{4}$ Geological Institute, Russian Academy of Sciences, Petrozavodsk, Karelia, Russia \\ ${ }^{5}$ Geological Institute, Russian Academy of Sciences, Apatity, Kola, Russia
}

MS received 22 October 1993

\begin{abstract}
The middle to late Archaean rocks of Kola and Karelia in the eastern Baltic shield consist of the Infracomplex overlain by the Saamian complex, and the Lopian greenstone belts. The Infracomplex which forms the basement is a polymigmatite, parts of which are at least $3100 \mathrm{Ma}$ old. The Saamian in the central Belomorian region comprises granite gneiss, amphibolite, garnet-kyanite gneiss and high alumina gneisses which belong to the Keret, Hetolombina and Chupa suites. The Lopian greenstone belts ranging in age from 3000 to $2700 \mathrm{Ma}$ are composed of peridotitic, pyroxenitic and basaltic komatiites, tholeiitic basalts, andesites, dacites and rhyolites, together with tuffs, graywackes and iron formations. Whereas there is a dominance of volcanic over sedimentary rocks in the greenstone belts of the Baltic shield, a significant proportion of detrital and chemogenic sedimentary rocks characterizes the Dharwar succession of approximately the same time span in the southern Indian shield. Association of mature and immature detrital sedimentary focks with bimodal volcanic assemblages points to a back-arc setting for the Dharwar belts. This contrasts with the association of immature sediments with calc-alkaline volcanic rocks in the greenstone belts of the eastern Baltic shield, suggesting an island arc environment there.
\end{abstract}

Keywords. Archaean; Dharwar; eastern Baltic shield; Infracomplex; Peninsular Gneiss; southern India.

\section{Introduction}

In an earlier publication, we gave a brief summary of the Archaean greenstone belts of the eastern Baltic and the southern Indian shields, highlighting the similarities and differences between these two ancient terranes (Srinivasan et al 1992). In this paper we present details of sedimentary-volcanic associations of the greenstone belts (Lopian = late Archaean) in parts of Karelia and Kola in relation to the adjacent gneisses, as well as the high-grade schists and gneisses (Saamian, believed to be midArchaean) of the Belomorian belt. Finally, we compare them with the Archaean geology of the schist-gneiss complex of the Dharwar craton in southern India.

\section{Archaean geology of the eastern Baltic shield}

The basement rocks termed as the Infracomplex are overlain by volcano-sedimentary sequence of the Saamian complex of high metamorphic grade and the Lopian complex 


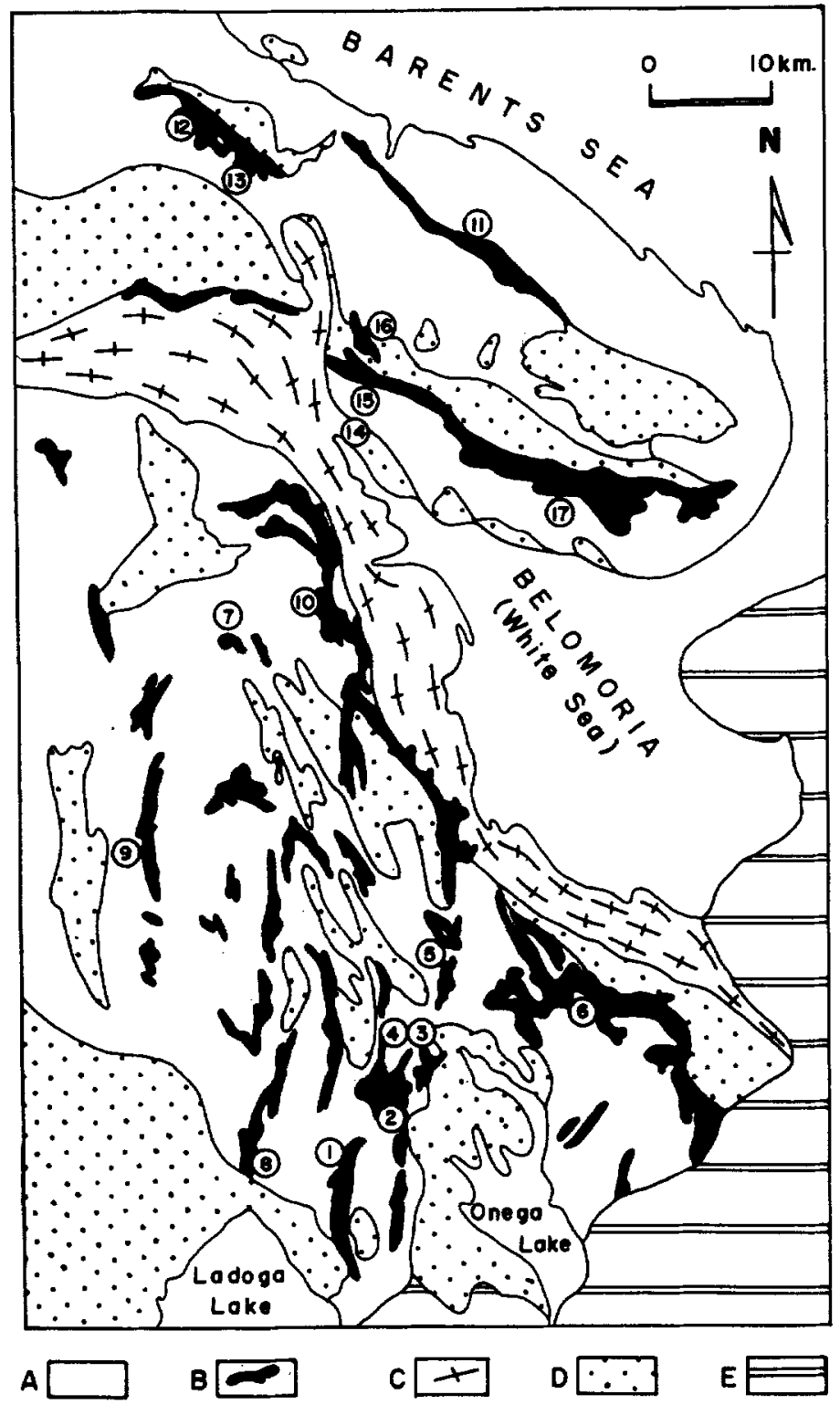

Figure 1. Geological map of the Archaean terranes of Karelia and Kola Peninsula of the eastern Baltic shield, Russia. (A) Infracomplex including Saamian; (B) Lopian greenstone belts; (C) Belomorian mobile belt; (D) Other Proterozoic rocks; (E) Platform cover. (1) Hautavaara; (2) Semch; (3) Koikari; (4) Oster; (5) Palaja Selga; (6) Kamennoozerskaya (7) Kostamooksha; (8) Jalonavaara; (9) Kuhmo-Suomussalmi; (10) Hizovaara; (11) PolmosPoros; (12) Kaskamskaya; (13) Allarechenskaya; (14) Kandalaksha; (15) Cis-Imandra; (16) Trans-Imandra; (17) Tersk.

of low- to medium-metamorphic grade (Rundquist and Mitrofanov 1993). The Saamian complex is considered by one group of workers to be older than the Lopian complex (Sokolov and Heiskanen 1985; Stenar 1988), whereas the other view is that these two complexes are equivalent in time, but differ only in metamorphic grade 
(Kozevnikov et al 1992). There is unanimity of opinion that a part of the tonalitic gneisses in the Infracomplex represents the basement. There is, however, divergence of views as to whether the enclaves of supracrustal rocks within the Infracomplex are of Saamian or Lopian age. The distribution of the Lopian greenstone belts in Karelia and Kola, and the Infracomplex including the Saamian is shown in figure 1.

\section{The Infracomplex}

The Infracomplex forming the basement in the eastern Baltic shield is composed dominantly of tonalitic gneisses. The gneisses are widely distributed in the Kola and Belomorian regions and occur between the greenstone belts in Karelia. As in other Archaean terranes, these gneisses have been extensively reworked, and involved in multiple deformation, metamorphism and migmatization. Small to large enclaves of gabbro-anorthosite, two-pyroxene granulites, enderbites, and supracrustal rocks of amphibolite facies occur within these gneisses. At some places e.g., in Palaja Selga area, darker gneisses with an earlier fabric transected by the foliation of the gneissic host occur as relicts (figure 2). U-Pb age of zircon from these inclusions is $3100 \mathrm{Ma}$, whereas the zircons of the host gneiss are $2900 \mathrm{Ma}$ (Rybakov and Svetova 1992).

The rocks of the supposed Infracomplex on the northern shores of the Kandalaksha Bay are considered by a number of workers now to represent a highly metamorphosed portion of supracrustal rocks of probable Lopian age. A two kilometre thick gabbroanorthosite suite within the Infracomplex has been involved in two phases of granulite facies metamorphism, followed by retrogression to amphibolite facies and migmatization (figure 3). Isoclinal folding of one generation preceding the three phases of deformation affecting the greenstone belts has been noted. This has led workers to

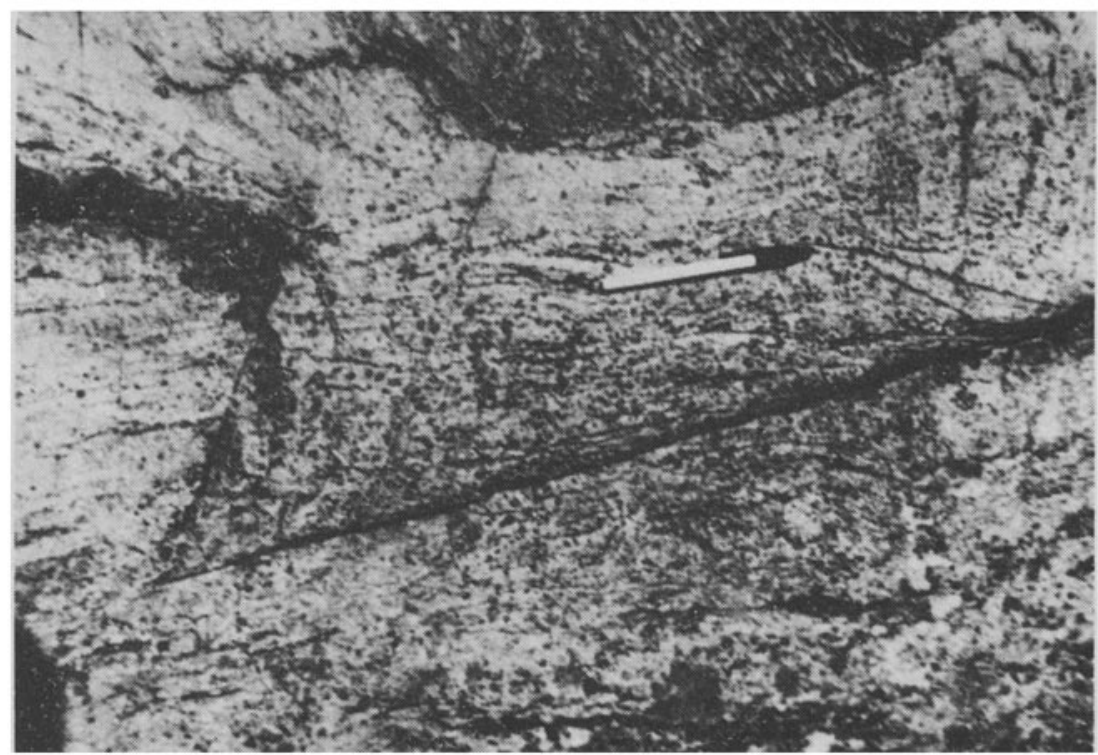

Figure 2. Tonalitic gneiss inclusion with an earlier fabric transected by later foliation in a gneissic host which is also tonalitic; Infracomplex, Palaja Selga, Karelia. 


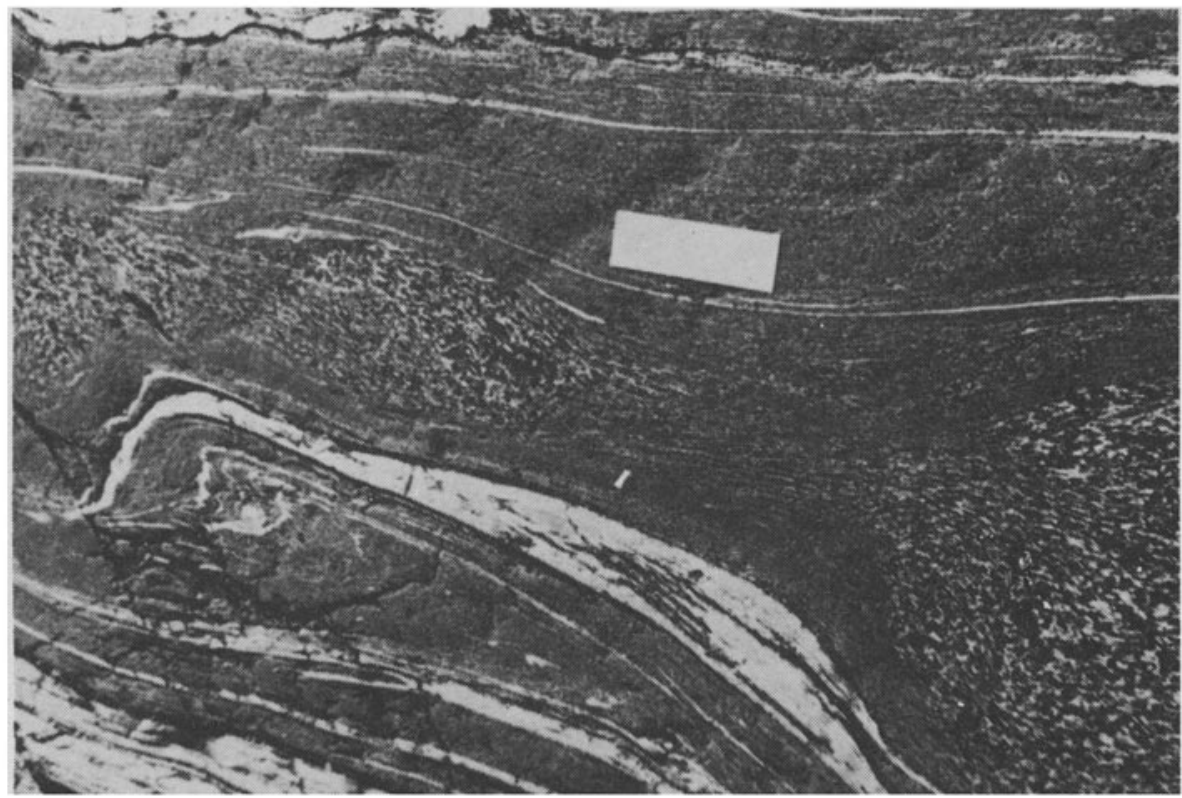

Figre 3. Coarse grained amphibolite boudins within thinly foliated finer grained amphibolite in the gabbro-anorthosite body of the Infracomplex affected by migmatization, Tolstick area, northern shores of Kandalaksha Bay.

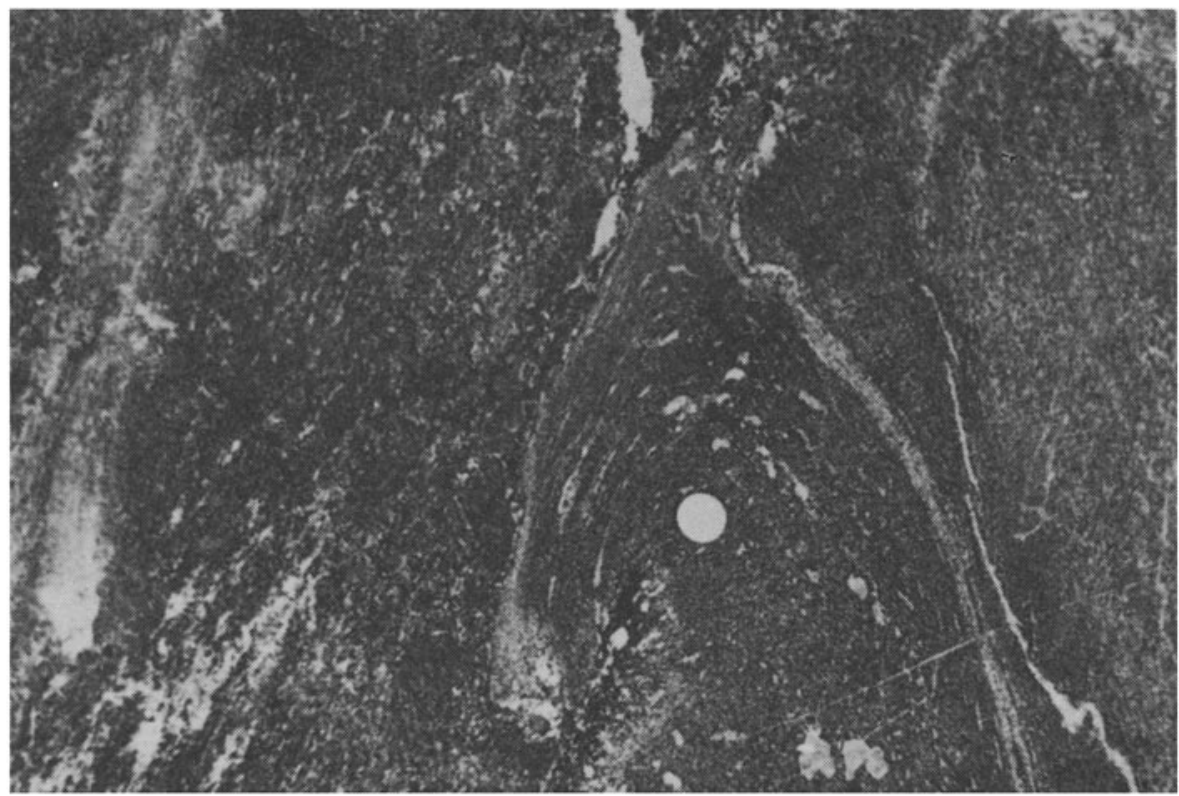

Figure 4. Megacrysts of plagioclase in gabbro within the Infracomplex involved in tight folding. Leonard Bivaka, northern shores of Kandalaksha Bay. 
suggest that the gabbro-anorthosites form a part of the original basement. These rocks have been transformed into either amphibolites or enderbites during the first phase of regional metamorphism. Breccias with different size and shape of fragments and diverse proportions of garnet, hornblende, plagioclase and pyroxene, are seen within the gabbro-anorthosite rocks. These have been interpreted by some as volcanic breccia, whereas some others have taken them to be of tectonic origin.

In addition to the massive gabbro-anorthosite, small pockets of anorthosite as well as plagioclase megacrysts in metagabbros have been involved in folding, suggesting an early synkinematic growth of plagioclase (figure 4). Anorthosite bands involved in folding and showing an axial planar fabric traced by feldspar grains also point to synkinematic evolution of anorthosite with respect to this folding.

Inclusions of two-pyroxene granulite in various stages of transformation by deformation and migmatization have been noted at a number of places in the Infracomplex. The granulites devoid of plagioclase are considered to be metapyroxenites, whereas those with plagioclase are believed to be metagabbros. The metagabbros give an $\mathrm{Rb}-\mathrm{Sr}$ isochron age of $3100 \mathrm{Ma}$ which is considered to be a metamorphic age. The tonalitic gneiss forming the host gives an age of $2700 \mathrm{Ma}$. Occurrence of these inclusions in a tonalitic host confirms that these are indeed a part of the basement complex on which the supracrustal rocks of Lopian (and Saamian) age were laid down. Thin dykes of amphibolite of Lopian age intruding the gabbro-anorthosite show pinch-and-swell structure parallel to the foliation of the host rocks and have been involved in later folding (figure 5).

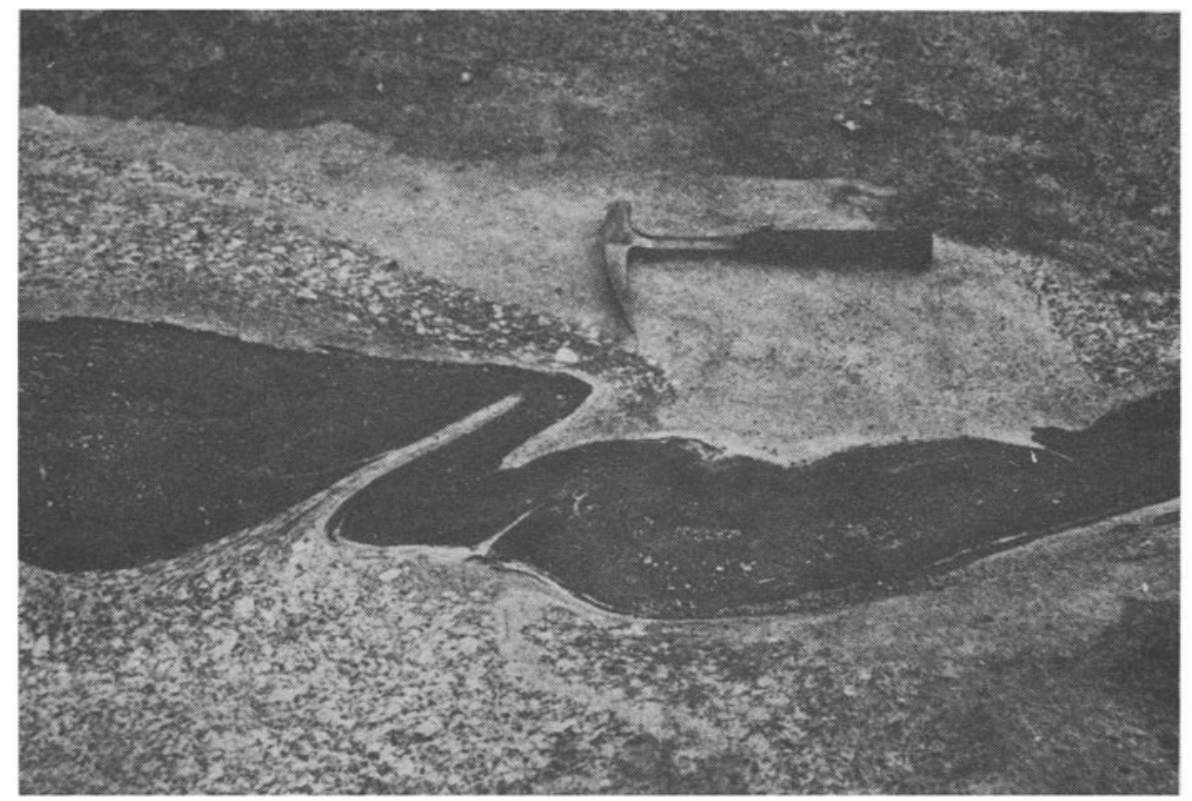

Figure 5. Basic dyke of Lopian age intruding the Infracomplex showing pinch-and-swell structure and subsequent folding, Lessozovaadski area, northern shores of Kandalaksha Bay. 


\section{Metamorphosed supracrustal rocks in the Infracomplex}

Within the gneisses of the Infracomplex occur some components which are of undoubted supracrustal origin. Some of these have been grouped together under the Saamian complex, whereas other occurrences have remained unclassified. The Saamian complex is best exposed in the Belomorian region. The central Belomorian region near Ambarny in Karelia constitutes the type section where all the components of the Saamian complex are represented (Kozevnikov et al 1992). The Saamian complex is composed of three suites in order of decreasing age - Keret, Hetolombina and Chupa. The Keret suite comprises granite gneiss with amphibolite becoming predominant in some portions. The Hetolombina is composed of amphibolites with garnet and kyanite gneisses in some parts. The Chupa suite is represented by high alumina gneisses (figure 6).

A broad similarity of rock units of these three suites renders it difficult to place isolated rock outcrops to a particular position in the Saamian succession. However, a well exposed large synclinorium in the Ambarny area seems to justify a sequence of Keret, Hetolombina and Chupa succession from the flanks to the core. Multiple deformation and large-scale migmatization make it difficult to distinguish the Saamian rocks from the Infracomplex (figure 7). The stratigraphic position of the Saamian becomes all the more problematic in view of the fact that they become indistinguishable from the Lopian complex, particularly where the latter is migmatized. Relevant in this context is the observation that the metasedimentary and meta-igneous rocks of the Saamian complex occurring as enclaves in the Keret area pass along strike into metamorphosed sedimentary-igneous complex of the supposedly younger Lopian complex in the Hizovaara area (Slabunov 1991; Kozevnikov et al 1992). Thus the

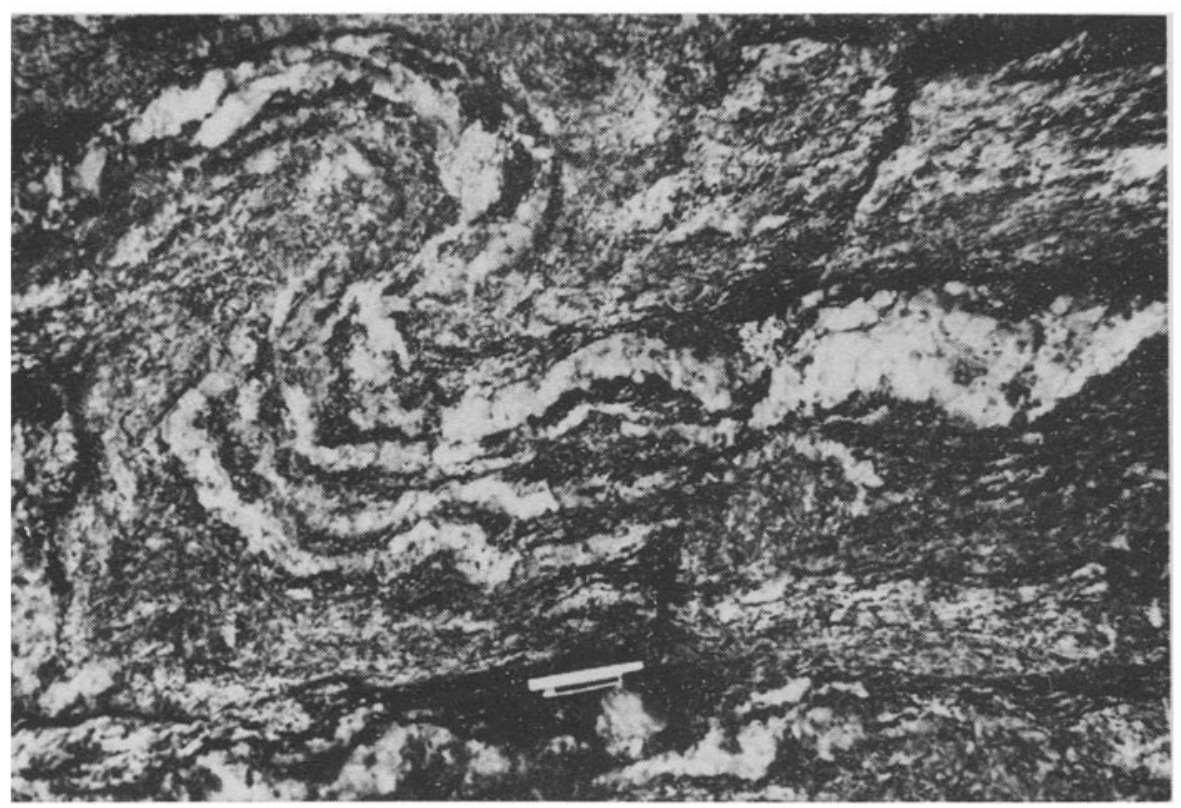

rigure b. Folded kyanite gneiss, Hizovaara area. 


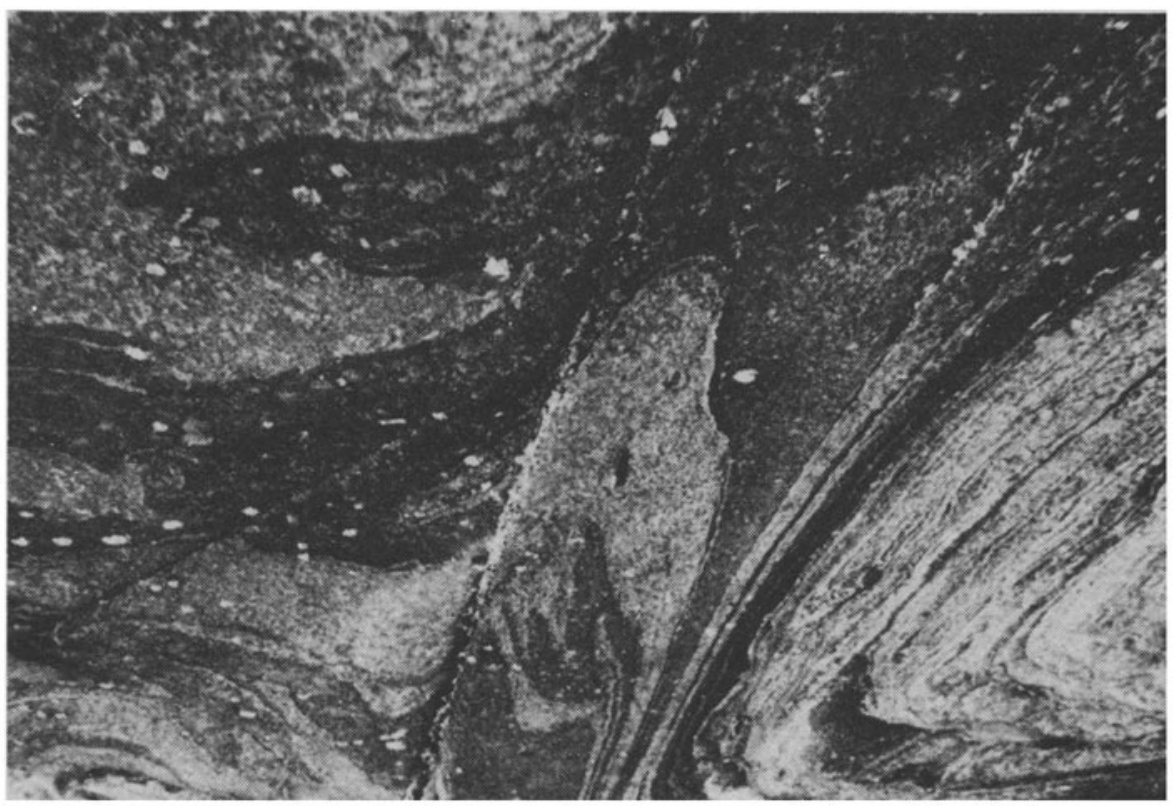

Figure 7. Migmatitic gneiss belonging to Saamian complex with axial planes of folds in diverse orientation, Ambarny area, Belomorian region.

position of the Saamian complex as a separate stratigraphic entity becomes doubtful, as the relation with the underlying Infracomplex and the overlying Lopian complex is ambiguous.

In addition to the Saamian complex there are other supracrustal enclaves of doubtful stratigraphic affinity within the Infracomplex. For example, amphibolite, marble, quartzite and conglomerate crop out within the composite gneisses on the northern shores of the Kandalaksha Bay in the Kola Peninsula. Pebbles, cobbles and boulders of the metaconglomerate are dominantly tonalitic (figure 8). Less common are pebbles of amphibolite, hypersthene diorite and quartz. The metaconglomerates represent an erosional interface between the Infracomplex and supracrustal rocks, the latter having been migmatized and metamorphosed in the amphibolite facies. These conglomerates are overlain by metamorphosed graywacke, tuff, amygdular basalt and ultramafic schists which also occur as inclusions. Isoclinally folded conglomerates with an axial planar schistosity have again been involved in isoclinal folding. Open folds on subhorizontal axial planes superimposed on all these structures represent the third deformational event. These latest folds have affected the quartz veins also. Biotiteamphibole clusters forming part of the matrix are segregated in the hinge zones of some of these folds, suggesting neomineralization with mobility of elements even during the last deformation.

At some places amphibolites associated with the metaconglomerates alternate with banded marble. This association suggests that the amphibolites are of sedimentary parentage. The schistose and banded amphibolites with sharp difference in composition of alternate bands pose a problem regarding their original composition. The layered character, the sharp variation in the composition of different layers, and the unusual 


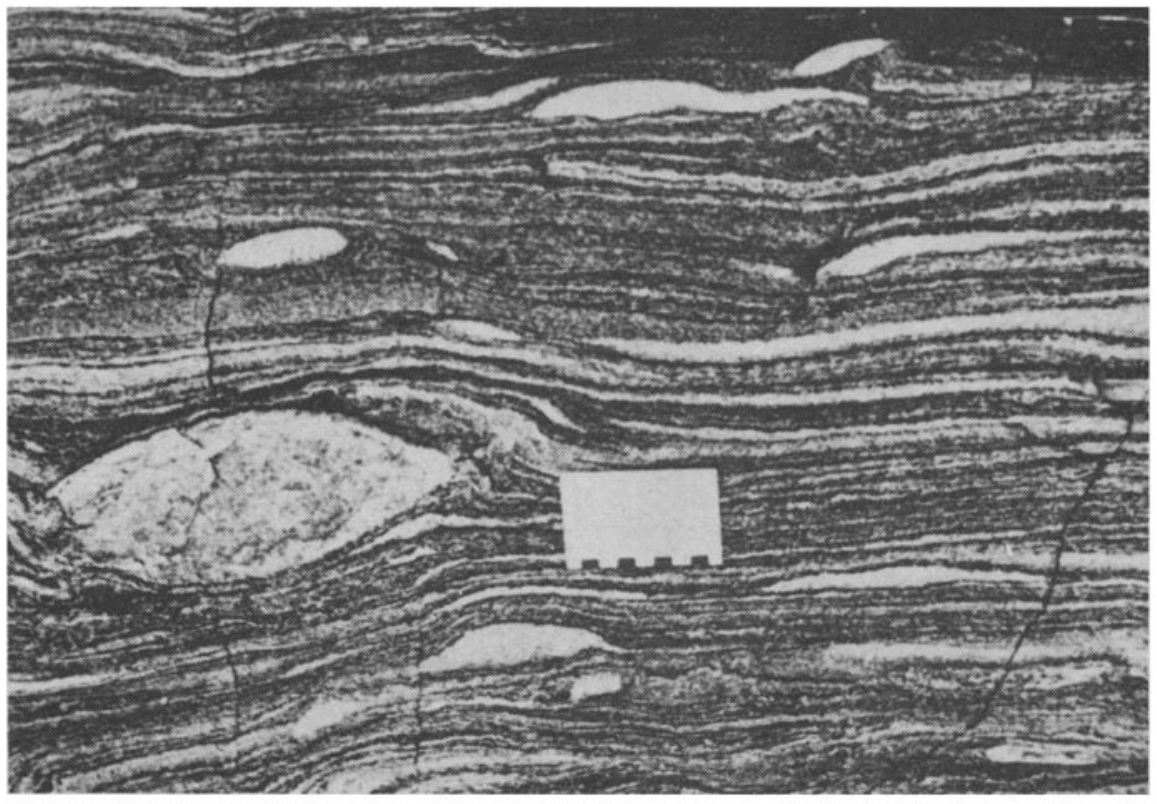

Figure 8. Conglomerate with migmatized matrix in the Infracomplex. Ryezanovy Ludy, northern shores of Kandalaksha Bay.

composition of certain layers (comprising, for example, clinopyroxene, calciferous hornblende and garnet) suggest that these rocks have been derived from partly terrigenous, partly volcanic and partly volcaniclastic materials. Metamorphism is of low pressure amphibolite facies.

\section{The Lopian complex}

The dominant supracrustal sequence of Archaean age in the Kola and Karelia regions is the Lopian complex which occurs as several discrete greenstone belts (Rybakov 1988). Some of the more important ones in Karelia are the Hizovaara, Palaja SelgaKoikari-Semch-Hautavaara, and Kostamooksha belts. The relation of the Lopian complex with the Infracomplex is blurred either by migmatization or by tectonic movement along contact or by invasion of younger granites (Lobach-Zhuchenko et al 1986). None of the belts mentioned above contains the whole sequence of the Lopian complex, and a complete succession can be reconstructed only from a composite picture from all the belts.

In the Hizovaara belt the Lopian complex comprises volcanic and volcanosedimentary rocks bordered by tonalites and granites with intrusive contacts. The succession starts with metamorphosed peridotitic komatiites, tholeiitic basalts, basaltic to peridotitic komatiites and ferrotholeiites associated with pyroclastic rocks. These are followed by basaltic andesites and andesites (figure 9). The foregoing volcanic sequence is overlain by a dominantly sedimentary succession represented by volcanogenic turbidites and terrigenous sediments. This succession starts with a quartz 


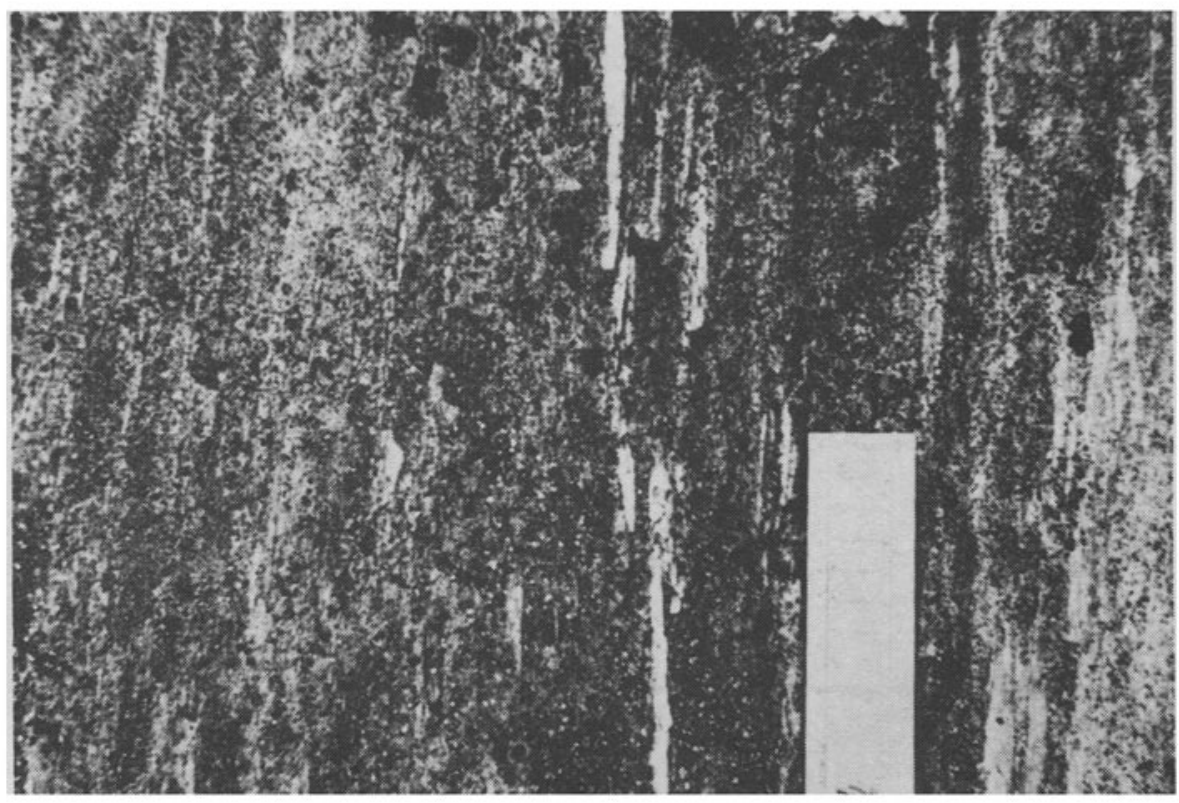

Figure 9. Lopian meta-andesite with quartz amygdules stretched parallel to fold axis (parallel to scale). Hizovaara area, Karelia.

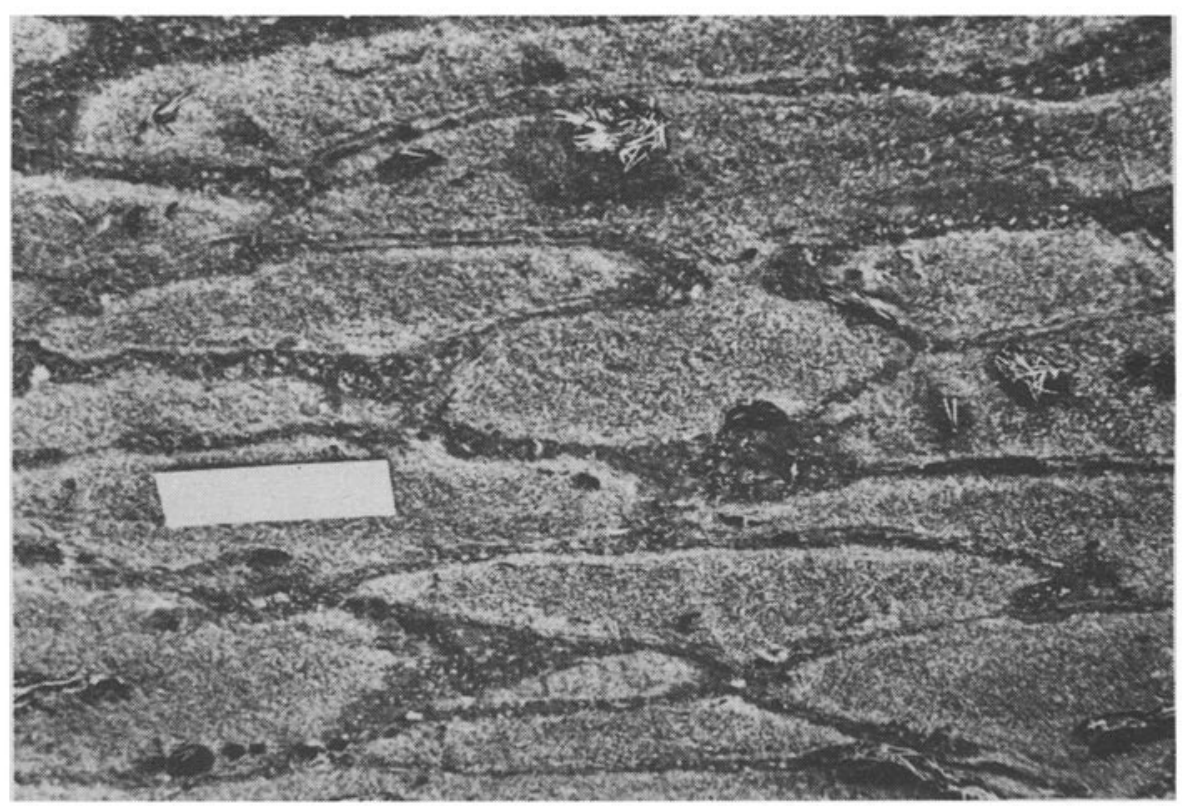

Figure 10. Garnetiferous amphibolite retaining pillow structure, Lopian sequence, Hizovaara belt, Karelia. 


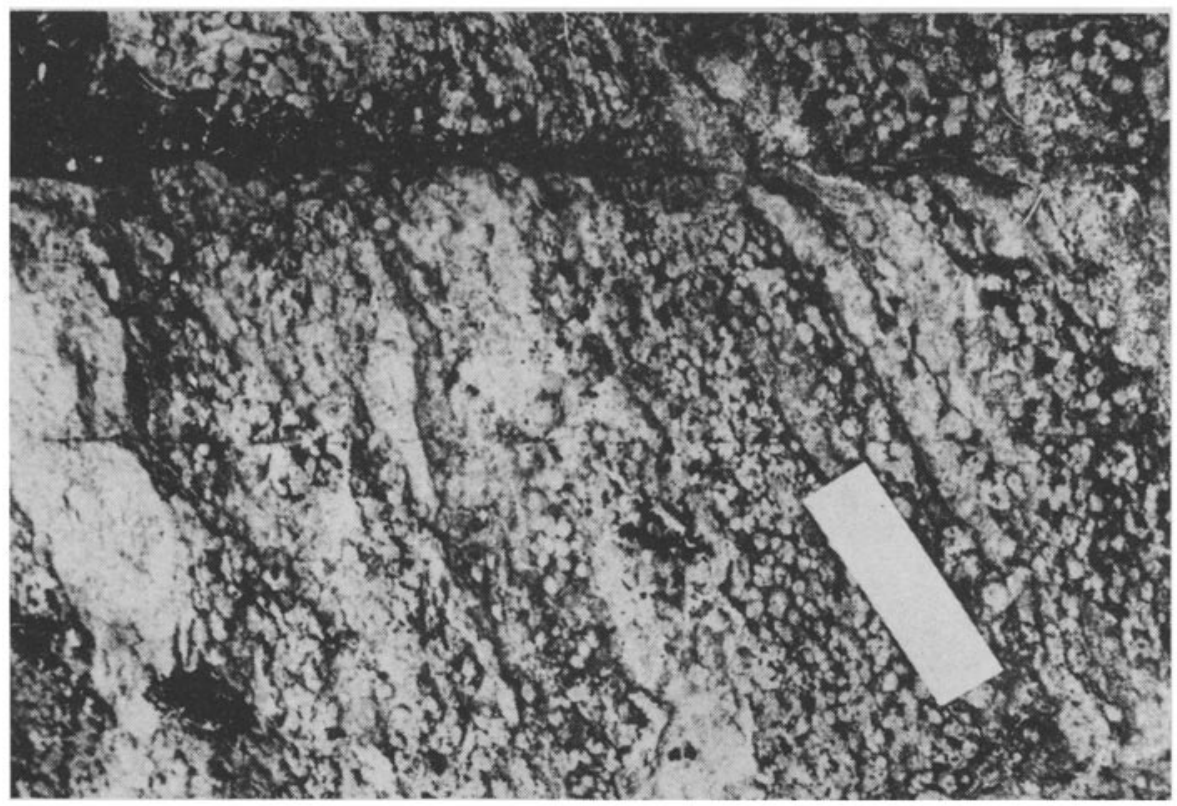

Figure 11. Garnet-amphibole-quartz rock, Lopian Group, Hizovaara.

arenite and is followed by turbidites which have been metamorphosed to schists containing kyanite, staurolite, garnet, amphibole, muscovite, biotite, fuchsite, magnetite and graphite. This succession is in turn overlain by a volcanic complex represented by metamorphosed pillow basalts with local development of peridotitic komatiites, pyroxenites and gabbros. The pillow lavas are highly deformed and metamorphosed to garnetiferous amphibolites (figure 10) which at some places pass into garnet-quartzhornblende rock (figure 11). Dykes of basalt, andesite, dacite and rhyolite intruding especially into the lower sections of the stratigraphic column represent the last cycle of magmatic activity in this greenstone belt. The $2800 \mathrm{Ma}$ age for the rhyodacite dyke fixes the upper age limit for the Lopian rocks of the Hizovaara belt. This belt, with the nature of volcanic assemblage detailed above, is a typical example of a greenstone belt with calc-alkaline volcanism (Kozevnikov et al 1992).

The rock formations of Hizovaara can be traced over a distance of 80 kilometres into the Keret greenstone belt in the Belomorian region (Slabunov 1991). The supracrustal rocks of the Keret belt have been divided into three suites. The lower unit consists of metamorphosed komatiites and tholeiitic basalts. The middle unit comprises epidote-amphibole-biotite or biotite schists, which contain volcaniclastic fragments indicating that they have been formed from volcanic tuffs and agglomerates (figure 12). Their composition varies from andesitic basalt, through andesite to dacite. The upper unit consists of para-gneisses. The Keret greenstone belt is bordered by a gneissic zone to the west. The succession of rocks here is not different from the one in the greenstone belt except for a higher grade of metamorphism and migmatization. In the gneissic zone the lower unit consists of amphibolites and kyanite-garnet-biotite gneisses interlayered with ultramafic rocks, some of which have komatiitic composition. This gneissic unit can be traced to the upper part of the adjoining Keret greenstone 


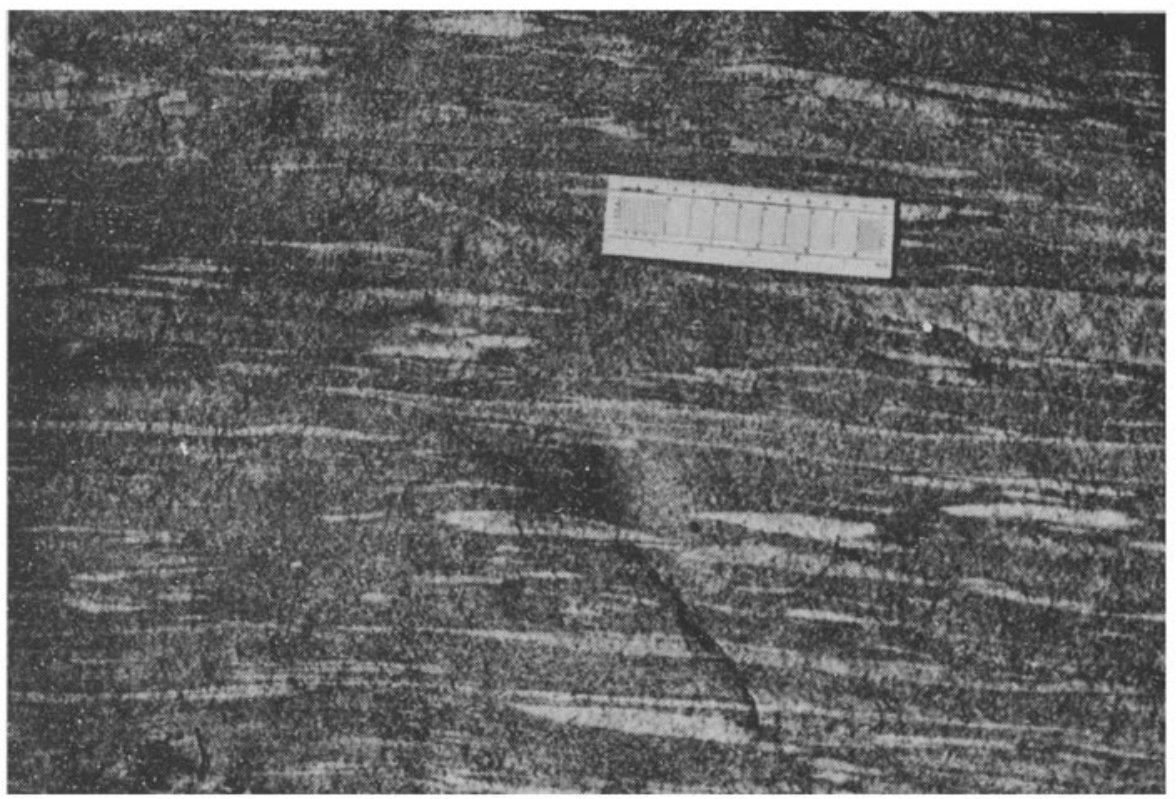

Figure 12. Hornblende gneiss considered to be a metamorphic variant of the Lopian volcaniclastic rocks, Hizovaara, Karelia.

belt. These are followed by high-alumina para-gneisses associated with garnetmagnetite rocks and amphibolites, which may correspond to the sequence that overlies the lower basalts and andesites in the Hizovaara greenstone belt (Kozevnikov et al 1992).

The transition of greenstone belt assemblages from the Lopian belt of Hizovaara to the Saamian type assemblage seen in the Keret area demonstrates that the Saamian assemblages indeed represent Lopian greenstone sequence metamorphosed to high grade. The upper age limit of $2700 \mathrm{Ma}$ for the complex as given by Tugarinov and Bibikova (in Rundquist and Mitrofanov 1993) corroborates the inference that the Saamian rocks of Keret region are a part of the late Archaean Lopian sequence.

The Palaja Selga-Koikari-Semch-Hautavaara greenstone belts form a part of the Vediozero-Segozero palaeovolcanic belt in central Karelia (Rybakov and Svetova 1992). They crop out in a NNE-SSW zone with Palaja-Selga in the north, Koikari and Semch in the middle and Hautavaara in the south.

The Palaja Selga is the smallest of these belts. Migmatites and granites border the belt on the eastern and western sides. The supracrustal rocks in the belt comprise a lower pillow basalt, a middle peridotitic to pyroxenetic komatiite and an upper quartz tholeiite sequence. These are intruded by andesitic dykes whose age is $\sim 3000 \mathrm{Ma}$. They have been invaded by tonalites and microcline granites, the latter giving zircon $\mathrm{Pb}-\mathrm{Pb}$ age of $2890 \mathrm{Ma}$. The grade of metamorphism increases from greenschist facies in the centre to amphibolite facies in the borders.

In the Koikari and Semch areas, the Lopian complex has been divided into three formations. The lower formation consists of peridotitic komatiites and tholeiitic basalts. The komatiitic flows show a well-developed cumulus base, spinifex textured 


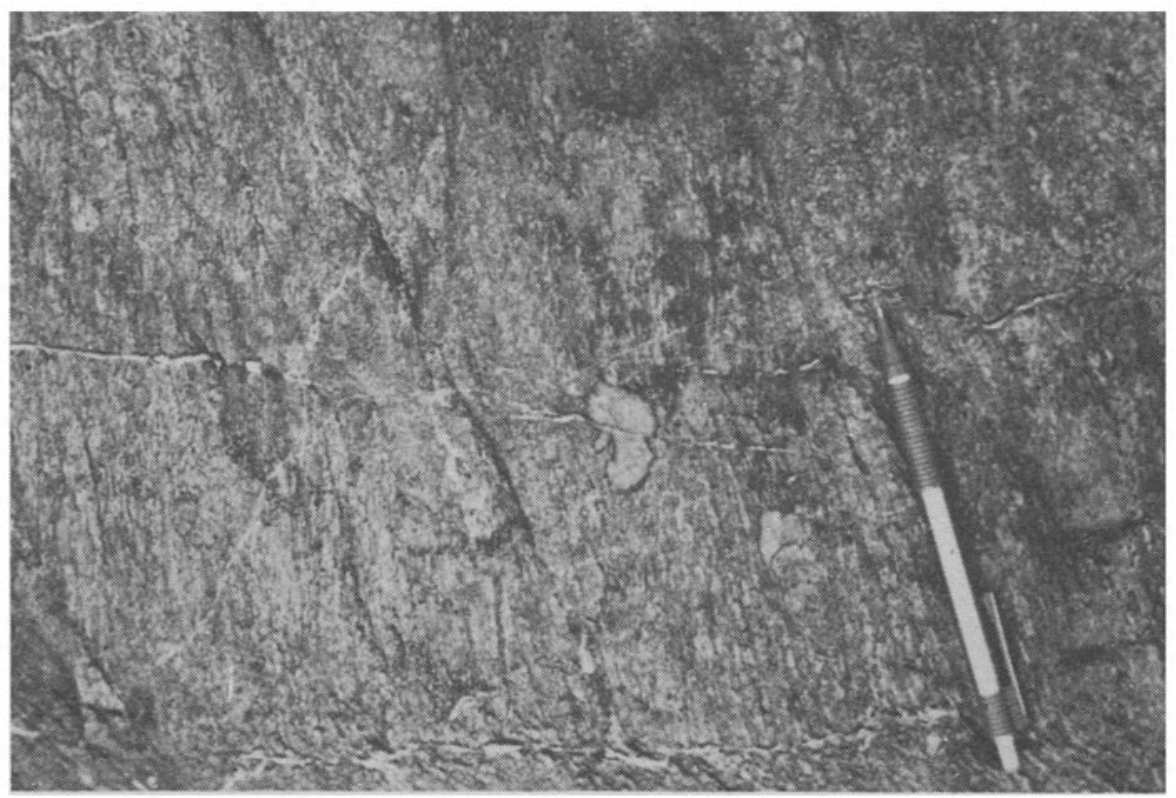

Figure 13. Lopian komatiite showing spinifex blades, Koikari belt, Karelia.

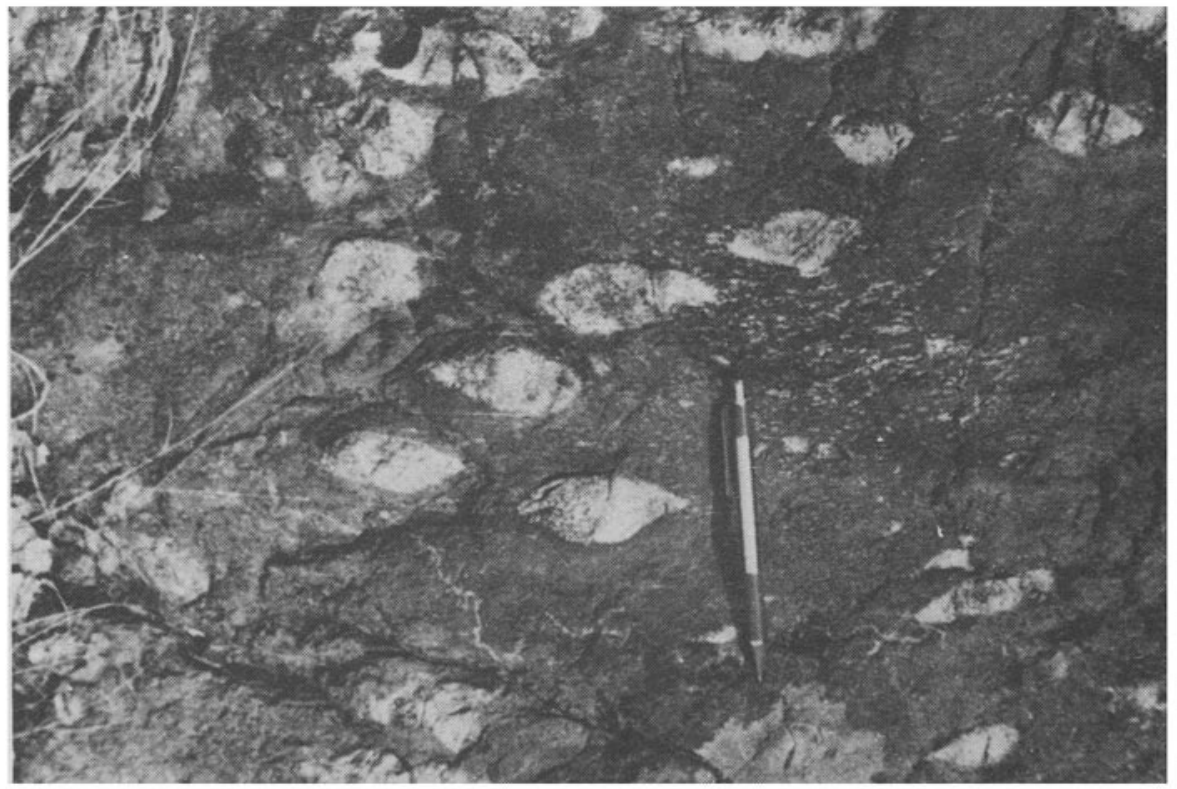

Figure 14. Andesitic varioles in Lopian basalt, Koikari area, Karelia. 
central part (figure 13) and lava tops with contraction cracks. The basalts exhibit well-developed pillow and variolitic structures (figure 14). The middle formation composed of polymictic conglomerates and graywackes, basalts and basaltic tuffs, carbonaceous schists and dolomites, rests on a weathered crust of peridotitic komatiites and basalts represented by a chlorite schist. This volcano-sedimentary sequence is intruded by dacitic dykes. Zircon $\mathrm{U}-\mathrm{Pb}$ age of these dykes is $2935 \pm 20 \mathrm{Ma}$, thus fixing the upper age of the Lopian complex in this section.

The Lopian sequence in Hautavaara is much more complete than in Palaja Selga or Koikari-Semch sections. Unlike in Hizovaara, Koikari and Semch, the volcanic sequence starts here with andesitic basalts and andesites, which give $\mathrm{U}-\mathrm{Pb}$ zircon ages of $2995 \pm 20 \mathrm{Ma}$ (Rybakov and Svetova 1992). On the basis of similarity in rock types the peridotitic komatiites and basalts overlying the andesitic sequence in Hautavaara have been correlated with the lowermost part of the Koikari and Semch sections. The belt has been affected by metamorphism in amphibolite facies resulting in the development of cordierite, andalusite, staurolite and garnet (figure 15).

The Lopian sequence in the Kostamooksha greenstone belt comprises a lower volcanic and an upper sedimentary assemblage (Gorkovetz and Rayevskaya 1992). The volcanic assemblage consists of three units. The lowermost unit comprises quartz tholeiites exhibiting pillow structures. Very thin komatiitic tuffs metamorphosed to tremolite-chlorite schist or garnetiferous amphibolite have been locally observed. These are overlain by rhyodacitic flows and tuffs in the middle unit. In the upper part of the middle unit, iron formation composed of magnetite and quartz with subordinate grunerite, biotite and pyrrhotite occurs. This unit is followed by metabasalts of olivine tholeiite composition belonging to the upper unit. These are pillow basalts which at

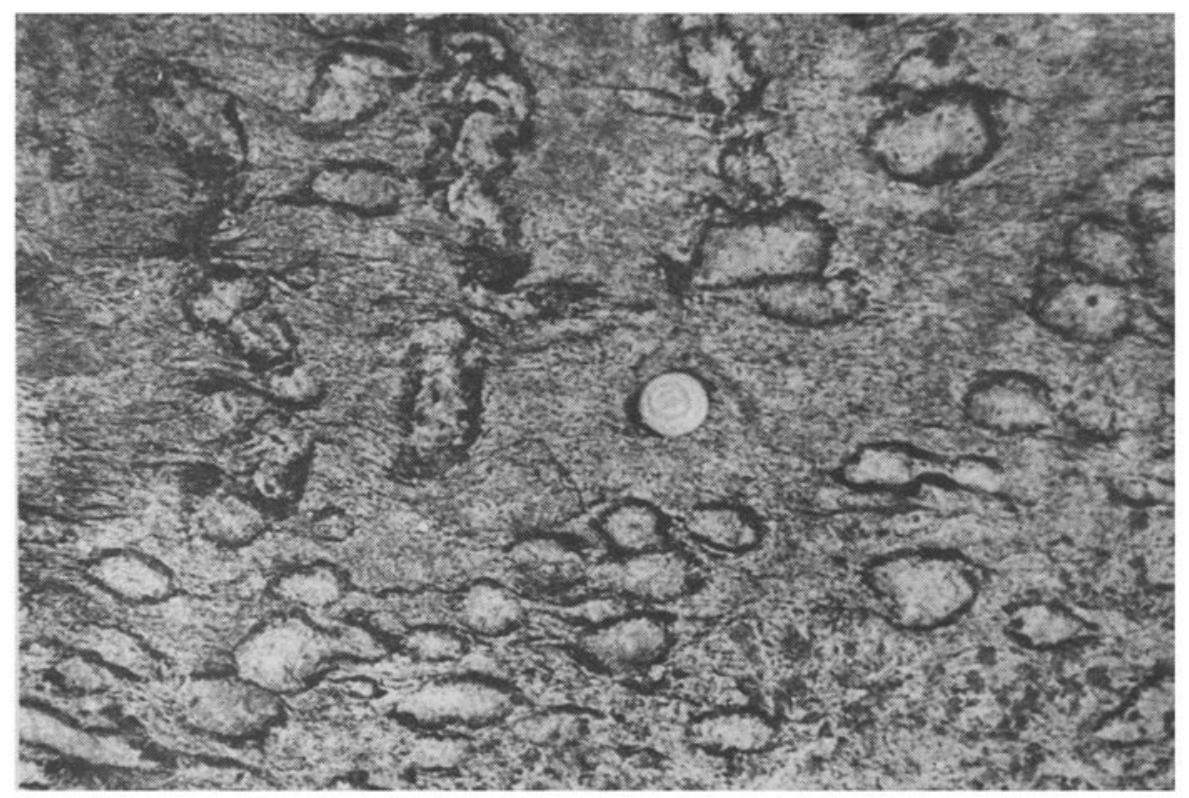

Figure 15. Cordierite-andalusite-staurolite-garnet schist formed by metamorphism of Lopian andesitic tuffs, Hautavaara belt, Karelia. 


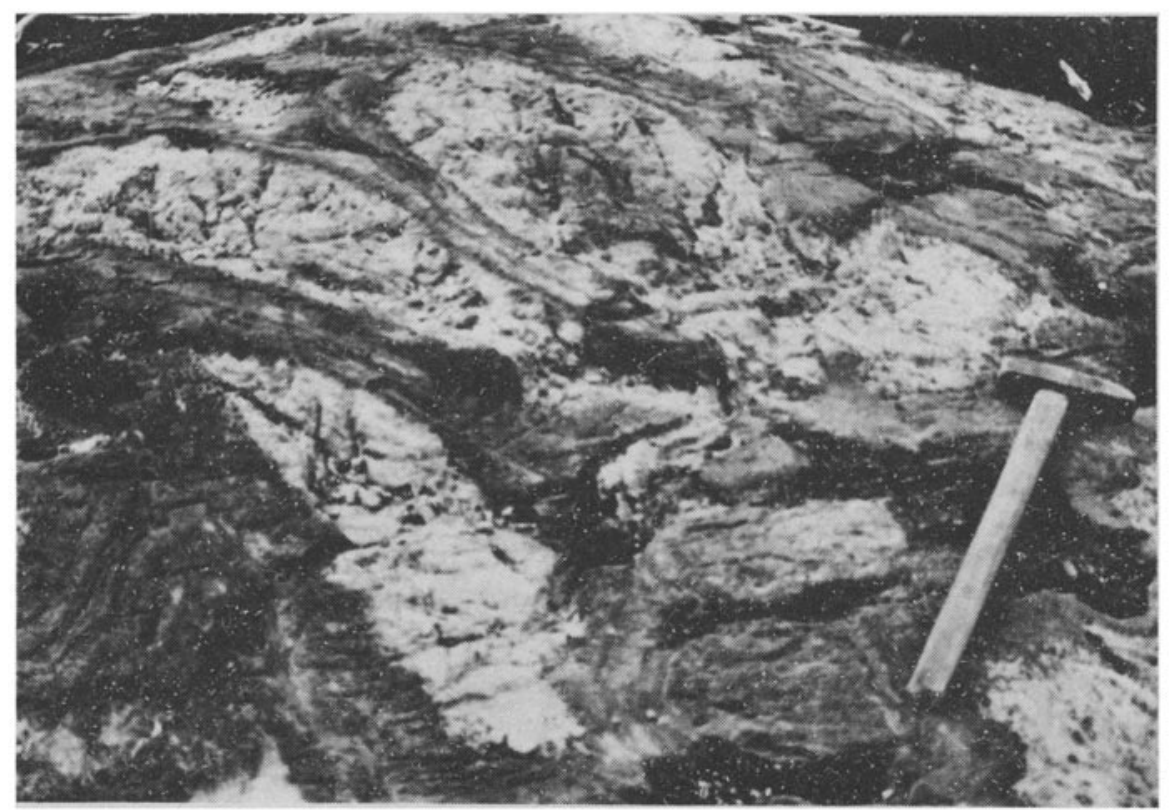

Figure 16. Lopian basalts with pillows having andesitic core and basaltic rims, Kostamooksha belt, Karelia.

some places show andesitic core and basaltic rim (figure 16). In the uppermost part, komatiitic lavas exhibiting pillow structure, spinifex texture and contraction cracks interbedded with tuffs have been noted.

On the weathered crust of the upper volcanic unit polymictic conglomerates belonging to the sedimentary assemblage crop out. They are composed of pebbles derived from the underlying volcanic suite and much less abundant tonalitic pebbles from the basement. The matrix of the conglomerate is a graywacke which contains volcanic rock fragments. The conglomerate is followed by the Kostamooksha iron formation comprising magnetite and grunerite with local development of riebeckite and pyrite. The main iron formation of Kostamooksha, which is interlayered with graywacke, is intruded by a rhyodacite dyke. Meta-arkoses (paragneiss) underlying the iron formation and overlying the basement gneisses have been migmatized at about $2700 \mathrm{Ma}$ age. Similar ages have been recorded from granites intruding the Kostamooksha sequence and the rhyodacite dyke which has affected the Kostamooksha iron formation.

In the southern Kola Peninsula, Lopian supracrustal rocks metamorphosed to amphibolite facies have been reported from Cis- and Trans-Imandra zones of the Tersk segment (Rundquist and Mitrofanov 1993). In the Cis-Imandra zone on the western shores of lake Imandra, a polymictic conglomerate is believed to overlie the Infracomplex. The conglomerate is composed of pebbles of tonalitic gneiss, plagiomicrocline granite, aplite and metabasic rocks in a volcaniclastic matrix. Although the contact between the supracrustal rocks and the Infracomplex is considered by majority of workers to mark an original erosional unconformity, the interface has been largely blurred by shearing in a $4 \mathrm{~km}$ wide zone. This is indicated by extensive mylonitization, 


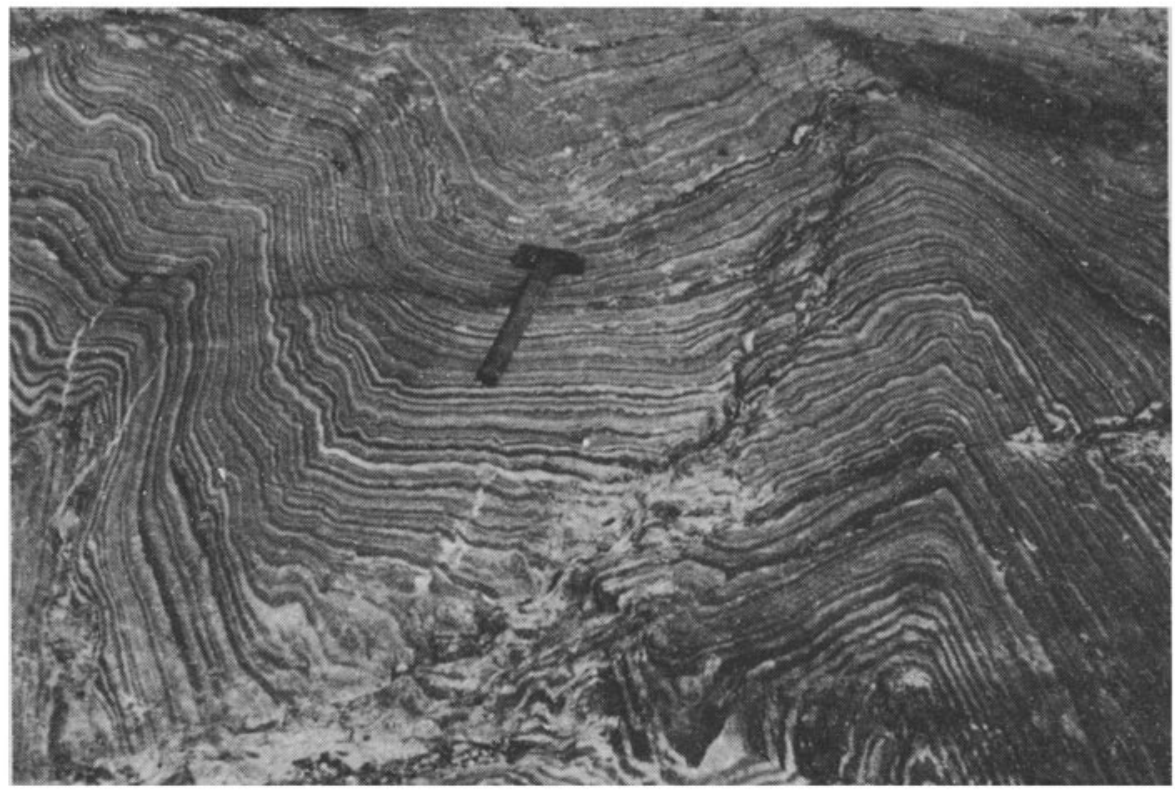

Figure 17. Banded iron formation involved in folding, Pecheguba area, Trans-Imandra belt, Kola.

and flattening and stretching of the pebbles in the conglomerates. These conglomerates, which occur in four horizons, are interbedded with dacite flows and followed by pillowed basalts. In the Pecheguba area of Trans-Imandra zone, the supracrustal rocks are represented by metamorphosed basalts, dacites and rhyolites interbedded in the upper part with banded iron formation (figure 17). The whole sequence has been metamorphosed in the upper amphibolite facies. These supracrustal rocks of medium grade metamorphism have been taken by some workers to be Saamian, whereas others have considered them to be Lopian rocks in higher metamorphic grade (Rundquist and Mitrofanov 1993).

\section{Eastern Baltic shield and Dharwar craton: A comparison}

A comparison of the Archaean geology of the eastern Baltic shield of Karelia and Kola with that of the southern Indian shield (figure 18) brings out striking similarities as well as some significant differences. Like in many other shield areas of the world, the basement gneisses (the Infracomplex in the Baltic shield and the Peninsular Gneiss in southern India) are extensively reworked in different phases. Consequently, the problem of finding unmodified basement on which the oldest supracrustal rocks were deposited is acute. As mentioned earlier, the Infracomplex consisting dominantly of tonalitic gneiss has at some places darker gneisses with an earlier fabric as relicts of the possible unreconstituted basement. A major part of the Infracomplex is considered to be polymigmatitic and affected by multiple deformations. Identical features are obtained in a large number of outcrops in the Peninsular Gneiss in southern India. As detailed elsewhere (Naha et al 1986, 1990, 1991), at least one phase of metamorphism, 
migmatization and deformation $\left(\mathrm{DhF}_{*}\right)$ preceded the most dominant deformation and migmatization affecting the Peninsular Gneiss and the supracrustal rocks of the Dharwar craton $\left(\mathrm{DhF}_{1}\right)$. In the Karelian province in particular, zircon from the relict tonalitic enclaves have furnished a $\mathrm{U}-\mathrm{Pb}$ age of $3100 \mathrm{Ma}$, whereas the host gneisses yield ages of $\sim 2900 \mathrm{Ma}$. This $3100 \mathrm{Ma}$ age is also given by some gabbro-anorthosite enclaves forming a part of the Infracomplex. In the southern Indian shield the oldest gneisses dated are 3200 to $3300 \mathrm{Ma}$, whereas the major part of the Peninsular Gneiss gives ages clustering around 3000 and $2600 \mathrm{Ma}$ (Beckinsale et al 1982; Bhaskar Rao et al 1991; Taylor et al 1988).

The Dharwar supracrustal belts in the southern Indian shield and the Lopian belts in the Baltic shield occur as enclaves within the supposed basement gneisses. However, the relation between the gneisses and the supracrustal rocks in both the shields is ambiguous. Whereas Foote (1886) considered the Peninsular Gneiss ('Fundamental Gneiss') to be the basement on which the Dharwar supracrustal rocks were laid down, Smeeth (1915) took the Peninsular Gneiss to be younger than the Dharwar rocks. Rama Rao (1940), however, appreciated the more complex relation between the two rock groups. According to him the basement gneisses on which the rocks of the Dharwar Group were deposited, have been modified by repeated anatexis, so that the Peninsular Gneiss in its present state is largely post-Dharwar in age. Likewise, in the Baltic shield, the Infracomplex has been affected by repeated phases of

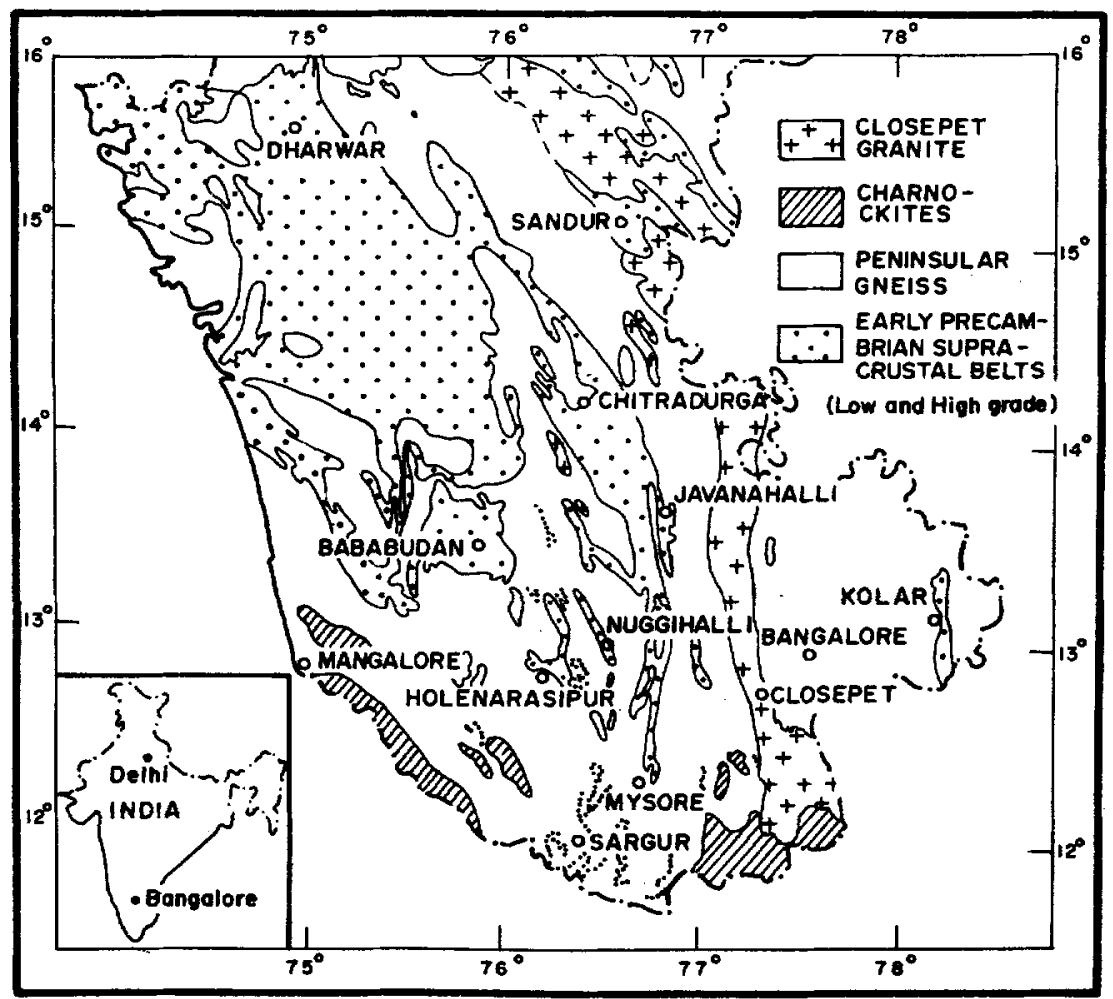

Figure 18. Geological map of the Dharwar craton, southern India. 
migmatization. Although in a number of places the contact between the supracrustal rocks and the Infracomplex is marked by shearing or by invasion of younger granites $(2700 \mathrm{Ma})$, supracrustal rocks (pillow lavas, conglomerates, arkoses and tuffs) partially migmatized to form a part of the Infracomplex can be demonstrated in the Kandalaksha Bay area, and the Kostamooksha and Hizovaara-Keret belts.

There is a striking similarity in the interrelation between the Lopian and the Saamian supracrustal belts of the Baltic shield on the one hand, and between the Dharwar and the supposedly older Sargur groups of rocks in the south Indian shield on the other. Whereas the rocks of the Saamian complex are extensively migmatized so that it is difficult to differentiate them from the Infracomplex in many instances, the supposedly younger Lopian rocks constitute well-defined supracrustal belts. Detailed mapping in the Keret-Hizovaara belts has shown the continuity of the Lopian rocks into the Saamian, so that the Saamian now is taken to be a higher grade metamorphic variant of the Lopian rocks (Kozevnikov et al 1992). In the southern Indian shield, the Sargur Group was taken to be older than the Dharwar Group on the strength of higher metamorphic grade, more complex deformation and migmatization (Swami Nath and Ramakrishnan 1981). As detailed elsewhere (Srinivasan 1988), the rocks of the Dharwar group also show complex deformation and have been migmatized. Shorn of metamorphic impress the rocks of both the groups are identical in a number of instances. Furthermore, in some cases (e.g., Chitradurga belt) the rocks of the Dharwar group can be traced continuously along strike into the rocks of the supposed Sargur group towards the south. An identical situation is obtained in the Javanahalli belt along the eastern margin of the Chitradurga belt (Ghosh Roy and Ramakrishnan 1985).

There are, however, some significant differences in the characters of the supracrustal belts of the two shield areas:

(1) Whereas the Lopian Group of the Baltic shield is dominantly volcanic with a minor proportion of sedimentary rocks mainly in the upper part, terrigenous sediments are present throughout the Dharwar succession (Holenarasipur, Nuggihalli, Bababudan and Chitradurga) and form a considerable part of the stratigraphic column.

(2) Uraniferous quartz pebble conglomerates are present in the lower part of the Dharwar succession, unlike in the Karelian greenstone belts.

(3) Extensive occurrence of iron and manganese formations as well as limestones in the southern Indian belts is in sharp contrast with restricted occurrence of iron, total absence of manganese and negligible proportion of carbonate rocks in the Archaean terrane of the Baltic shield. Major deposits of iron formation in the Dharwar region are associated with volcanic rocks, whereas iron formations in the Kostamooksha belt (the most important iron formations in Karelia) are interbedded with graywacke.

(4) Wide development of stromatolites in the Archaean carbonate rocks of the Dharwar supracrustal belts has no parallel in the Lopian belts of Karelia.

(5) In contrast with the extensive occurrence of komatiitic rocks in the lower and middle parts of the succession in the Lopian greenstone belts, komatiites form a very small proportion of volcanic suite in the Dharwar terrane. The ultramafic rocks of the latter area occur as layered complexes unlike in the Karelian region. The volcanic assemblages in the Dharwar belts are bimodal in character with a 
tholeiite-rhyodacite association (e.g., Bababudan, Chitradurga, Kolar, Sandur belts). The Baltic shield, by contrast, is characterized by greenstone belts which consist of bimodal as well as calc-alkaline assemblages.

(6) Unlike in the Baltic shield the Dharwar belts host gold deposits, as well as small deposits of copper and chromite.

The basement complexes and the supracrustal belts of both the eastern Baltic and the southern Indian shields cover a comparable time span of Middle to Late Archaean $(3300$ to $2600 \mathrm{Ma}$ ). But the differences enumerated above suggest that the sialic crust forming the basement for the Dharwar supracrustal belts was thicker and stronger, and therefore could support stable zone volcanism, sedimentation and biological activity. By contrast, immature sediments associated with dominantly submarine volcanic rocks point to a thin and unstable sialic crust forming the basement of the Karelian greenstone belts. The calc-alkaline volcanism in the Karelian greenstone belts suggest an island arc setting (Gaal 1986), whereas the bimodal volcanism in the Dharwar belts indicate a back-arc setting (Srinivasan et al 1992).

\section{Acknowledgements}

This study is a part of the work carried out under Indo-Russian Integrated Long Term Project No. B-2.4 of the Department of Science and Technology, Government of India, and the Russian Academy of Sciences. Grateful thanks are due to Prof. V K Gaur, Dr. K Gopalan and the Director of the National Geophysical Research Institute, Hyderabad, for their keen interest. Logistic support provided by the Chitradurga Copper Unit of the Hutti Gold Mines, Mysore Minerals Limited, and Mysore Cements Limited is thankfully acknowledged. The authors record with gratitude the help rendered by the scientists of the Vernadsky Institute, Moscow; Institute of Precambrian Geology, St. Petersberg; Geological Institute of Karelia, Petrozavodsk; and the Kola Centre of the Academy of Sciences, Apatity. Thanks are also due to Drs. Bibikova, Bogdanova, Gorkovetz, Kozevnikov, Kulikova, Rayevskaya, Slabunov, Sokolov, Svetova and Vinogradov for perceptive discussions in the field.

\section{References}

Beckinsale R D, Reeves-Smith G, Gale N H, Holt R W and Thompson B 1982 Rb-Sr and Pb-Pb whole rock isochron ages and REE data for the Archaean gneisses and granites, Karnataka State, South India; Indo-US Workshop on the Precambrian of South India, National Geophysical Research Institute. Hyderabad, Abstracts pp. 35-36

Bhaskar Rao Y J, Naha K, Srinivasan R and Gopalan K 1991 Geology, geochemistry and geochronology of the Archaean Peninsular Gneiss around Gorur, Hassan District, Karnataka, India; Proc. Indian Acad. Sci. (Earth Planet. Sci.) $100399-412$

Foote R B 1886 Notes on the geology of parts of Bellary and Anantapur districts; Mem. Geol. Surv. India $211-40$

Gaal G 19862200 Million years of crustal evolution: the Baltic shield; Bull. Geol. Soc. Finland 58 149-168

Ghosh Roy A K and Ramakrishnan M 1985 Stratigraphic status of the Javanahalli belt in the Archaean geology of Karnataka; J. Geol. Soc. India $26567-597$

Gorkovetz V Y and Rayevskaya M B 1992 Archaean sequence in the Kostamooksha iron ore deposit area (geologic field guide); Russian Acad. Sci., Karelia Centre, Petrozavodsk, 38 p. 
Kozevnikov V N, Slabunov A Y and Systra Y Y 1992 Guide-book on the Geological excursion of northern Karelia, Karelian Research Centre; Russian Acad. Sci., Petrozavodsk 63 p.

Lobach-Zhuchenko S B, Levchenkov O A, Cheklaev V P and Krylov I N 1986 Geological evolution of the Karelian granite-greenstone terrain; Precambrian Res. 33 45-65

Naha K, Srinivasan R and Naqvi S M 1986 Structural unity in the early Precambrian Dharwar tectonic province, Peninsular India; Q. J. Geol. Min. Metall. Soc. India 58 219-243

Naha K, Srinivasan R and Jayaram S 1990 Structural evolution of Peninsular Gneiss, an early Precambrian migmatitic complex from South India; Geol. Rundsch. 79 99-109

Naha K, Srinivasan R and Jayaram S 1991 Sedimentational, structural and migmatitic history of the Archaean Dharwar tectonic province, Southern India; Proc. Indian Acad. Sci. (Earth Planet. Sci.) 100 413-433

Rama Rao B 1940 The Archaean complex of Mysore; Bull. Mysore Geol. Depart. 17101 p.

Rybakov S I 1988 Volcanism, sedimentogenesis and stratiform ore formation in the Archaean greenstone belts of Soviet Karelia. In: Archaean Geology of the Fennoscandian shield (ed.) E Martila (Geol. Surv. Finland, Spec. paper. 4) pp. 179-188

Rybakov S I and Svetova A I 1992 Upper Archaean Vedlozero-Segozero greenstone belt, Karelia, Geologic Field Guide, Karelian Research Centre; Russian Acad. Sci., Petrozavodsk 94 p.

Rundquist D V and Mitrofanov F P (eds) 1993 Precambrian Geology of the USSR (Amsterdam: Elsevier) $528 \mathrm{p}$

Slabunov A Y 1991 Late Archaean sedimentary and volcanogenic deposits in the boundary zone between the Karelian and Belomorian segments of the Baltic shield in the Lake Keret Area, northern Karelia (on the relation of Lopian and Belomorian supracrustal complexes); Minnesota Geol. Surv. Inf. Circular 34 122-127

Smeeth W F 1915 Outline of the geological history of Mysore; Bull. Dept. Mines and Geology, Mysore State No. 6, 1-21

Sokolov V A and Heiskanen K I 1985 Evolution of Precambrian volcano-sedimentary lithogenesis in the southeastern part of the Baltic shield; Geol. Surv. Finland Bull. 331 91-106

Srinivasan R 1988 Present status of the Sargur Group of the Archaean Dharwar craton, south India; Indian J. Geol. $6057-62$

Srinivasan R, Naha K, Bhaskar Rao Y J, Gopalan K, Vrevsky A B, Rybakov S I and Golubev A I 1992 Archaean greenstone belts of the eastern Baltic and the southern Indian shields - a comparative study; Curr. Sci. 62 741-744

Stenar M M 1988 Stratigraphy of Archaean deposits of Soviet Karelia. In Archaean Geology of the Fennoscandian Shield (ed.) E Martila (Geol. Surv. Finland Spec. Paper, 4) pp. 7-13

Swami Nath J and Ramakrishnan M (eds) 1981 Early Precambrian supracrustals of southern Karnataka; Geol. Surv. India Mem. 112351 p.

Taylor P N, Chadwick B, Friend C R L, Ramakrishnan M, Moorbath S and Viswantha M N 1988 New age data on the geological evolution of southern India (Abstract); J. Geol. Soc. India 31 155-157 